\title{
Medication Adherence to Successful Tuberculosis Treatment Outcome among TB/HIV Patient at Prof. Dr. Sulianti Saroso Infectious Disease Hospital
}

\author{
Yusmaniar, Adin Hakim Kurniawan
}

Pharmacy Department, Poltekkes Kemenkes Jakarta II, Indonesia

\begin{abstract}
Tuberculosis/Human Immunodeficiency Virus (TB/HIV) co-infection has poorer treatment outcome compared to non-co-infected patients. To benefit from therapy and to avoid contracting treatment-resistant strains, the individuals must adherent to medications. There is limited information regarding successful TB treatment outcomes and their associated factors. Thus, the study was designed to identify medication adherence associated with treatment outcomes among TB/HIV Patients at Prof. Dr. Sulianti Saroso Infectious Disease Hospital. This research was an observational study with retrospective approach from January 2015 to December 2017 by taking data from medical records and TB-01 form of TB/HIV patients in the outpatient clinic of the disease which would be used as a sample. Regarding compliance in treatment with first visit for 2-4 months, an approach using secondary data which were TB-01 Form, as well as HIV Care and Antiretroviral Therapy summary forms was used. The statistical analysis used was the bivariate analysis with the chi-square test as the statistical test. A total of 114 patients were included in the study. The outcome of treatment success obtained from this study had a patient cure rate of $91.30 \%$. There is a significant relationship between medication adherence to successful tuberculosis treatment outcome with $\mathrm{p}$-value $=0.012 ; \mathrm{OR}=5.684$. There is a meaningful relation between medication compliance with treatment outcome. It is when on medication adherence, the treatment results can be declared cured in accordance with predetermined criteria, while when not on medication adherence, the treatment results are not declared cured.
\end{abstract}

Keywords: Medication Adherence, Treatment outcome, TB-HIV Patient

\section{Introduction}

In 2018, there were 37.9 million people living with HIV respectively, and 3.8 million of them were living in 11 countries of the SouthEast Asia Region. Indonesia is one of SouthEast Asia country with the fastest-growing epidemics. Human Immunodeficiency Virus (HIV) and Acquired Immunodeficiency Syndrome (AIDS) in Indonesia remains concentrated in sub-populations exposed to an elevated risk of HIV transmission due to their behaviors. ${ }^{1}$

In 2015, it was estimated that 613.435 People Living with HIV and AIDS (PLWHA) in Indonesia. These people are commonly referred to as "Key Populations" including direct and indirect female sex workers, drugs

Corresponding author: Adin Hakim Kurniawan. Pharmacy Department, Poltekkes Kemenkes Jakarta II, Indonesia.

Email: addienhakim@gmail.com

Received: 16 August 2020. Revised: 19 November 2020. Published: 10 December 2020 
users, homosexual and transgender people. In 2013, the estimated prevalence among the national adult population is $2.3 \%{ }^{2}$

Tuberculosis (TB) is a serious health threat and untreated latent TB infection can quickly progress to TB disease in PLWHA due to weakening the immune system. In the worldwide, TB is one of the leading causes of death among PLWHA. ${ }^{2,3}$ Low medication adherence can be particularly problematic due to prolonged treatment, higher costs, new cases elevation, and multidrug resistance development. These outcomes make treatment more complicated and expensive e $^{4,5}$

Individual behavior (non-adherence), individual characteristics, nutritional status, and CD4 are factors in unsuccessfulness of TB-HIV treatment. Adherence to both TB treatment and Anti-retroviral Therapy (ART) is a key determinant of TB/HIV treatment outcomes, including lower morbidity and mortality ${ }^{5}$, and essential to minimize the emergence of both TB and ART drug resistance. ${ }^{6}$ TB treatment takes at least 6 months; thus, it can increase patient noncompliance which can affect the successful therapy.

Studies in India, Swaziland, Thailand, and Zambia showed that the treatment of TB patients failed because they stop the medication when feeling better and/or taking the medication in only 2 months. ${ }^{7}$ Infectious Disease Hospital (RSPI) of Prof. Dr. Sulianti Saroso is one of the government hospitals that has implemented the DOTS (Directly Observed Treatment Short course) strategy and is one of the places where HIV/TB patients are referred from the Puskesmas located in DKI Jakarta. HIV/AIDS team-work reported that the number of HIV patients in 2017 was estimated at 1716 people, and 144 were TBHIV co-infected patients. ${ }^{8}$
Patients with HIV/AIDS are a special group that is vulnerable and at high risk of contracting TB. At the same time, the dual resistance of TB bacteria to the ART MultiDrug Resistance (MDR) is increasingly becoming a problem due to unsuccessful cases. This situation will eventually lead to a TB epidemic that is difficult to be handled ${ }^{7}$, thus, we conducted this study to determine the prevalence of TB incidence in HIV/AIDS patients, a description of TB-HIV patients, and the pattern of TB-HIV treatment and its therapeutic outcomes at RSPI Prof. Dr. Sulianti Saroso Jakarta.

\section{Methods}

This research was an observational study with retrospective approach from January 2015 to December 2017 in the disease outpatient clinic, RSPI Prof. Dr. Sulianti Saroso, Jakarta. The study received approval from the Ethical clearance of the Prof. Dr. Sulianti Saroso Infectious Disease Hospital ethical committee and Poltekkes Jakarta II with number LB.02.01/I/KE/39/523/2018.

\section{Study Population}

The population in this study were medical record of TB patients aged over 17 years old who were still undergo pulmonary $\mathrm{TB}$ treatment until December 2017. The sociodemographic and clinical assessment data were collected.

\section{Inclusion dan Exclusion Criteria}

TB patients' medical records with this completeness of the data as follows:

1. Aged over 17 years old

2. Complete socio-demographic data (age, sex, education, occupation, sexual transmission)

3. Complete the treatment data (treatment pattern, acid-resistant bacteria value, and CD4 value). 
Adherence was assessed with an approach using secondary data were TB-01 form and medical record of ART used in patients living with HIV/AIDS and TB. Regarding compliance in treatment with the first visit for 2-4 months, the TB-01 form and ART summary forms were used. The patient was declared adherent if they undertake the routine treatment for at least 2-4 months and the Acid-Resistant Bacteria (ARB) value was negative. Uncomplete medical records were excluded in this study.

\section{Statistical Analysis}

Chi-square test was used following the type of data on the independent variables (age, sex, education, occupation, sexual transmission, treatment type category, and medication adherence) and the dependent variables (successful TB treatment outcome). Bivariate analysis was used to examine the relationship between medication adherence and successful TB treatment outcome among TB/HIV patients. ${ }^{10,11}$

\section{Results and Discussion}

There were 114 medical records used based on the inclusion and exclusion criteria. The socio-demographics of patients are shown in Table 1. Overall results of demographic characteristics (age, sex, education, occupation, and transmission) had no significance for successful TB treatment outcomes in HIV/TB patients.

The results showed that the majority of HIV positive patients were male $(\mathrm{n}=86 ; 74.40 \%)$. Previous study at Amertha Clinic of Kerti

Table 1. Socio-demographic Characteristics Associated with Successful Tuberculosis Treatment Outcome of TB/HIV Patients

\begin{tabular}{|c|c|c|c|c|c|}
\hline \multirow[b]{2}{*}{ Variable } & \multicolumn{4}{|c|}{ Socio-demographic Outcome } & \multirow[b]{2}{*}{$\begin{array}{l}\text { Odd } \\
\text { Ratio }\end{array}$} \\
\hline & $\begin{array}{l}\text { Successful } \\
\text { n }(\%)\end{array}$ & $\begin{array}{c}\text { Unsucessful } \\
\text { n (\%) }\end{array}$ & $\begin{array}{c}\text { Total } \\
\text { Patients } \\
\text { n }(\%)\end{array}$ & p- value & \\
\hline \multicolumn{6}{|l|}{ Sex } \\
\hline Male & $40(46.51)$ & $46(53.49)$ & $86(75.44)$ & 0.328 & 0.193 \\
\hline Female & $17(60.71)$ & $11(39.29)$ & $28(24.56)$ & & \\
\hline \multicolumn{6}{|l|}{ Age } \\
\hline $\begin{array}{l}\text { Unproductive Age } \\
\text { (>55 years old) }\end{array}$ & $6(66.67)$ & $3(33.34)$ & $9(7.89)$ & 0.512 & 0.046 \\
\hline $\begin{array}{l}\text { Productive Age } \\
\text { (18-54 years old) }\end{array}$ & $45(42.86)$ & $60(57.14)$ & $105(92.11)$ & & \\
\hline \multicolumn{6}{|l|}{ Education } \\
\hline Basic & $45(45.45)$ & $54(54.55)$ & $99(86.84)$ & 0.692 & 1.046 \\
\hline College & $6(40)$ & $9(60)$ & $15(13.16)$ & & \\
\hline \multicolumn{6}{|l|}{ Occupation } \\
\hline Unemployee & $24(52.1)$ & $22(47.8)$ & $46(59.6)$ & 0.585 & 0.894 \\
\hline Employee & $39(57.35)$ & $29(42.65)$ & $68(40.35)$ & & \\
\hline \multicolumn{6}{|l|}{ Transmission } \\
\hline Sexual & $56(54.9)$ & $46(45.10)$ & $102(89.47)$ & 0.821 & 0.793 \\
\hline Non Sexual & $7(58.33)$ & $5(41.67)$ & $12(10.53)$ & & \\
\hline
\end{tabular}


Table 2. Descriptive Summary for All Variables of $T$

reatment Characteristics of TB/HIV Patients in 2015-2017

\begin{tabular}{lcc}
\hline $\begin{array}{c}\text { Treatment and Clinical } \\
\text { Characteristic }\end{array}$ & $\begin{array}{c}\text { Total } \\
\mathbf{n = 1 1 4}\end{array}$ & $\begin{array}{c}\text { Percentage } \\
(\mathbf{\%})\end{array}$ \\
\hline Anti-retroviral Treatment & & \\
TDF + 3TC + EFV & 42 & 36.84 \\
TDF + 3TC + NVP & 23 & 20.19 \\
ZDV + 3TC + EFV & 22 & 19.29 \\
AZT + 3TC + NVP & 14 & 12.28 \\
AZT + 3TC + EFV & 13 & 11.40 \\
Tuberculosis Treatment (OAT) & & \\
First Line & 83 & 72.8 \\
Second Line & 31 & 27.2 \\
CD4 Clinical Outcome & & \\
CD4 $\leq$ 200 cell/mm & 56 & 49.91 \\
CD4 > 200 cell/mm & 58 & 50.90 \\
The Microscopical Examination & & \\
ARB: Negative & 79 & 69.29 \\
ARB: Positive & 35 & 30.71 \\
\hline
\end{tabular}

Praja Foundation in Denpasar showed that the number of male TB/HIV patients was higher in men $(57.60 \%) .^{12}$ Also, a similar study by Lisiana N (2011) showed that most TB-HIV patients were male $(84 \%) .{ }^{13}$ This result was also similar to the data from the Ministry of Health's Report on the Development of HIVAIDS in 2016 which stated that the majority of HIV/AIDS patients were men with transmission through sexual contact. ${ }^{14}$

The majority of the ages of TB/HIV patients were in the productive age (aged 18 to 54 years old; 92.10\%). The most productive age patients suffer from HIV because they tend to have risky behaviors. Behaviors at risk of transmission of HIV disease come from deviant lifestyles, such as free sex and injection drug use. ${ }^{15}$ The level of education can improve the ability of patients to solve problems and decisions making related to the disease because knowledge will make an opportunity for behavior change.
There were five different Anti-retroviral (ARV) that being used at the hospital. TDF $+3 \mathrm{TC}+\mathrm{EFV}$ was $36.84 \%$ used in the most first-line that prescribed in 83 items $(72.80 \%)$. (Table 2). Based on TB treatment guideline in 2016, the doctor has right in providing this prescribing pattern because the antiretroviral used in combination should be according to the dosage regimen. The use of potent combinations of ARV is to suppress HIV replication. The goal of therapy is to achieve the maximum suppressive effect of HIV replication. Its secondary goals to increase CD4 lymphocytes and improve quality of life. ${ }^{17}$

First-line ARV combination in adults uses 2 NRTI and 1 NNRTI. The first line of choice for adult ARV is Tenofovir, Lamivudine, and Efavirenz are available as Fixed-Dose Combination (FDC) while other combinations are alternative alloys. Tenofovir is not recommended for use because it has the same nephrotoxic effect as 
Table 3.Medication Adherence and Demographic Characteristics of Tuberculosis Treatment Outcome

\begin{tabular}{cccccc}
\hline \multirow{2}{*}{$\begin{array}{c}\text { Variable } \\
\text { Medication } \\
\text { adherence }\end{array}$} & $\begin{array}{c}\text { Successful } \\
\text { (Cured) n (\%) }\end{array}$ & $\begin{array}{c}\text { Failure Treatment } \\
\mathbf{n}(\%)\end{array}$ & $\begin{array}{c}\text { p- } \\
\text { value }\end{array}$ & $\begin{array}{c}\text { Odd } \\
\text { Ratio }\end{array}$ & $\begin{array}{c}\text { CI- } \\
\mathbf{9 5 \%}\end{array}$ \\
\hline Adherence & $63(91.30)$ & $6(8.69)$ & 0.012 & 5.684 & 0.970 \\
Unadherence & $10(22.22)$ & $35(77.78)$ & & & 10.219 \\
\hline
\end{tabular}

streptomycin used in anti-tuberculosis drug (ATD) regimens, thus, clinical monitoring must be considered. Tenofovir will not be given if the creatine clearance test is less than $50 \mathrm{~mL} / \mathrm{min}$ or in cases of diabetes mellitus, uncontrolled hypertension, and renal failure, whereas Zidovudine will not be given if the $\mathrm{Hb}$ is less than $10 \mathrm{~g} / \mathrm{dL}$ before therapy. ${ }^{17}$

Efavirenz had been recommended because it has less interaction with rifampicin. This interaction is lighter than Nevirapine when the Lopinavir/Ritonavir drugs used in secondline ARV combinations. Rifampicin activates enzymes that increase the metabolism of Lopinavir/Ritonavir and results in reducing plasma levels of Lopinavir/Ritonavir from minimum inhibitory concentratio. If Rifampicine is combined with Lopinavir/ Ritonavir (e.g in TB meningitis), it is recommended to increase the dose of Lopinavir/Ritonavir to be twinkly times of the therapy dose. However, both drugs are hepatotoxic, thus, it is necessary to monitor liver function intensively. ${ }^{18}$

There are two combinations of ATD for the treatment of TB. First-line treatment (Rifampisin (R)/ Isoniazid (H)/ Pyrazinamid (Z)/Etambutol (E); RHZE) is used for new TB cases, whereas the second-line treatment (Rifampisin (R)/ Isoniazid (H)/ Pyrazinamid (Z)/Etambutol (E)/Streptomisin (S); RHZES) is used for cases of dropouts, relapses, and failures. ${ }^{19}$ This type of ATD is chosen as the first line because it has a strong potential being a broad spectrum against mycobacterium tuberculosis. Rifampicin is one of the most effective ATD, along with isoniazid, as a basic regimen of tuberculosis treatment. Rifampicin is active against fast growing and slow growing bacteria ${ }^{20}$ because it can easily diffuse across cell membranes. The bactericidal activity of this drug depends on the ability of this drug to inhibit ribonucleotide acid (RNA) transcription ${ }^{21}$, therefore rifampicin has a potent ability to be used as the first line. ${ }^{22}$

The use of ATD in 114 patients is following the National Guidelines for TB Control. ${ }^{8}$ ATD consists of two categories. The first category was given to new pulmonary TB patients either with positive $A R B$ or with negative ARB, positive ARB shows in chest X-ray, and extrapulmonary TB patients. The second category gives to positive ARB patients who have been treated previously, such as relapse patients, patients who failed therapy, and patients with treatment after dropping out of treatment. $^{23}$

The outcome of treatment success obtained from this study was a patient cure rate of $91.30 \%$, while treatment failure and withdrawal rate was $8.69 \%$. In Table 3, there was a significant relationship between medication adherence and successful TB 
treatment outcome ( $\mathrm{p}$-value $=0.012$ and odd ratio $=5.684)$. Thus, the medication adherence was 5.684 times greater to affect the success $\mathrm{TB} / \mathrm{HIV}$ treatment comparing with nonadherence in the treatment.

Patients with pulmonary TB were declared to be adherent if they undergo regular treatments for six months. After completing the treatments, then the results of treatments in patients with pulmonary TB could be said to be cured if the respondents have met the predetermined criteria. The criteria were adequate pattern treatment, $\mathrm{ARB}$ examination declared as negative twice (intensive and endof-treatment phases), and serial radiology images remaining the same or having improvements. ${ }^{24}, 25$ Unrecovered patients were stated when they only completed treatment without ARB examination and chest radiographs at the end of treatment, pulmonary TB patients that passed away, moved somewhere treatment, lost to followup from treatment, or failing treatment.

\section{Conclusion}

There is a meaningful relation between medication compliance and treatment outcome. Medication adherence in the treatment result can declare cured following predetermined criteria, while when not on medication adherence, the treatment results declare unsuccessful (treatment failure).

\section{Conflict of interest}

This paper was written independently. All authors disclose that there no financial personal relationship with other people of organizations that can inappropriately influence the work.

\section{Aknowledgement}

We thank to staff in Poltekkes Kemenkes Jakarta II and Prof Dr. Sulianti Saroso Infectious Disease Hospital, Jakarta for the support in the implementation of this research.

\section{References}

1. UNAIDS. Unaids report shows that 19 million of the 35 million people living with HIV today do not know that they have the virus | UNAIDS. Press Release. Geneva. 2014.

2. Wijayanti F; Tarmizi S; Tobing V; Nisa T; Akhtar M; Trihandini I; Djuwita R. From the Millennium Development Goals to Sustainable Development Goals.: The response to the HIV epidemic in Indonesia: challenges and opportunities. Journal of Virus Eradication. 2016;2:2731.

3. Floyd K, Glaziou P, Houben RMGJ, Sumner T, White RG, Raviglione M. Global tuberculosis target and milestonbes set for 2016-2035: Definition and rationale. International Journal of Tuberculosis Lung Disease. 2018;227:723-30.

4. Kemenkes RI. Estimasi dan Proyekjsi HIV/AIDS di Indonesia Tahun 20152019. In: Direktorat Jenderal Pencegahan dan Pengendalian Penyakit. Jakarta; 2017. p. 1689-99.

5. Mitku AA, Dessie ZG, Muluneh EK, Workie DL. Prevalence and associated factors of TB/HIV co-infection among HIV Infected patients in Amhara region, Ethiopia. African Health Science. 2016;16:588.

6. World Health Organization. WHO treatment guidelines for drug-resistant tuberculosis : 2016 update. 2016

7. Elisabeth Sanchez-Padilla, Themba Dlamini, Alexandra Ascorra, Sabine Rüsch-Gerdes, Zerihun Demissie Tefera, Philippe Calain, Roberto de la Tour, Frauke Jochims ER, and Maryline Bonnet. High prevalence of multidrugresistant tuberculosis, Swaziland, 20092010. Emerging Infectious Disease. 
2012;18:29-27.

8. Kementrian Kesehatan Republik Indonesia. Program Pengendalian HIV AIDS dan PIMS di Fasilitas Kesehatan Tingkat Pertama: Petunjuk Teknis. Direktorat Jenderal Pencegah dan Pengendali Penyakit. 2016;

9. Williams BG, Gupta S, Wollmers M, Granich R. Progress and prospects for the control of HIV and tuberculosis in South Africa: a dynamical modelling study. Lancet Public Health. 2017;2:e223-30.

10. Hair JF, Black WC, Babin BJ, Anderson RE. Multivariate Data Analysis. Vectors. 2010.

11. Dahlan MS. Statistik Untuk Kedokteran Dan Kesehatan Deskriptif, Bivariat dan Multivariat. Dilengkapi Alikasi Menggunakan SPSS. 6th ed. Jatinagor: Alqaprint; 2014. Salemba Medika. 2014.

12. Nyoko YO, Putra IWGAE, Sawitri AAS. Hubungan Karakteristik Demografi, Klinis dan Faktor Risiko Terinfeksi HIV dengan Koinfeksi HIV/TB di Klinik Amertha Yayasan Kerti Praja Denpasar. Public Health and Preventive Medicine Archived Journal. 2014;2:95

13. Lusiana N, Karsana A, Noviyani R. Studi penggunaan obat anti tuberkulosis pada pasien TB-HIV/AIDS di RSUP Sanglah Denpasar tahun 2009. Fakultas MIPA Jurusan Farmasi Universitas Udayana Denpasar, Bali. Jurnal Manajemen Pelayanan Kesehatan. 2011;14(02):99107

14. Wang H, Wolock TM, Carter A, Nguyen G, Kyu HH, Gakidou E, et al. Estimates of global, regional, and national incidence, prevalence, and mortality of HIV, 19802015: the Global Burden of Disease Study 2015. Lancet HIV. 2016;3:e361-87.

15. Wagner KD, Pollini RA, Patterson TL, Lozada R, Ojeda VD, Brouwer KC, et al. Cross-border drug injection relationships among injection drug users in Tijuana,
Mexico. Drug Alcohol Dependence. 2011;113:236-41

16. Notoatmodjo S. Promosi Kesehatan dan Perilaku Kesehatan (edisi revisi 2012). Jakarta: rineka cipta. 2012.

17. Ernesha Webb Mazinyo, Lindsay Kim, Sikhethiwe Masuku,Joey L. Lancaster, Ronel Odendaal, Margot Uys, Laura Jean Podewils. Adherence to Concurrent Tuberculosis Treatment and Antiretroviral Treatment among Co-Infected Persons in South Africa, 2008-2010. PLoS One. 2016;11:1-13.

18. Kibret, Kelemu Tilahun AWY, Belaineh et al. Determinant Factors Associated with Occurrence of Tuberculosis among Adult People Living with HIV after Antiretroviral Treatment Initiation in Addis Ababa, Ethiopia: A Case Control Study. PLoS One. 2013;8:1-8.

19. Goodman Gilman A. Goodman \& Gillman's The Pharmacological Basis of Therapeutics. Mc Graw Hill Education. 2017.

20. Palomino J, Martin A. Drug Resistance Mechanisms in Mycobacterium tuberculosis. Antibiotics. 2014;3(3):31740.

21. Anastasia S. Kolyva and Petros C. Karakousis. Old and New TB Drugs: Mechanisms of Action and Resistance, Understanding Tuberculosis - New Approaches to Fighting Against Drug Resistance, Pere-Joan Cardona, IntechOpen. 2015.

22. Albanna AS, Smith BM, Cowan D, Menzies D. Fixed-dose combination antituberculosis therapy: A systematic review and meta-analysis. European Respiratory Journal. 2013

23. Vermund SH, Yamamoto N. Co-infection with human immunodeficiency virus and tuberculosis in Asia. Tuberculosis. 2007;87:S18-25.

24. Chengchao Zhou, Jie Chu, Jinan Liu, 
Ruoyan Gai Tobe, Hong Gen, Xingzhou Wang, Wengui Zheng LX. Adherence to Tuberculosis Treatment among Migrant Pulmonary Tuberculosis Patients in Shandong, China: A Quantitative Survey Study. PLoS One. 2012;7:1-6.

25. Ifebunandu N, Ukwaja K OS. Treatment outcome of HIV-associated tuberculosis in a resource-poor setting. Tropical Doctor. 2012;42:74-6.

\section{Keywords and Definition}

1. NNRTI $=$ Non Nucleotide Reverse Transcriptase Inhibitors (NNRTI's)

2. $\quad$ NRTI $=$ Nucleotide Reverse Transcriptase Inhibitors (NNRTI's)

3. $\mathrm{TDF}=$ Tenovovir

4. $\mathrm{TC}=$ Lamivudin

5. $\mathrm{EFV}=$ Efavirenz

6. $\mathrm{NVP}=$ Nevirapine

7. $\mathrm{AZT}=\mathrm{Zidovudine}$

8. $\mathrm{CD} 4=$ cluster of differentiation 4

9. RHZES $=$ Rifampisin (R) $/$ Isoniazid (H)/ Pyrazinamid (Z)/Etambutol (E)/ Streptomisin (S)

10. RHZES = Rifampisin (R)/ Isoniazid (H)/ Pyrazinamid (Z)/Etambutol (E)/ Streptomisin (S) 